\title{
Is There a Correlation between Helicobacter Pylori and Enterohepatic Helicobacter Species and Gallstone Cholecystitis?
}

\author{
Seyed Masih Fatemi ${ }^{1}$, Abbas Doosti ${ }^{2}$, Dariush Shokri ${ }^{3}$, Sadegh Ghorbani-Dalini ${ }^{4}$, \\ Morteza Molazadeh ${ }^{1}$, Hossein Tavakoli ${ }^{5}$, Mohammad Minakari ${ }^{6}$, Hamid Tavakkoli6,**
}

1. Department of Microbiology, Faculty of Basic Sciences, Islamic Azad University, Shahrekord, Iran

2. Department of Microbiology and Immunology, Medical School, University of Michigan, Ann Arbor, Michigan, USA

3. Nosocomial Infection Research Center, Isfahan University of Medical Sciences, Isfahan, Iran

4. Young Researchers and Elite Club, Jahrom branch, Islamic Azad University, Jahrom, Iran.

5. Department of Biology, University of British Columbia, Kelowna, Canada

6. Department of Gastroenterology, Isfahan University of Medical Sciences, Isfahan, Iran

\footnotetext{
* Corresponding Author:

Hamid Tavakkoli, MD

Associate Professor of Gastroenterology, Department of Gastroenterology, Al-zahra Hospital, Isfahan University of Medical Sciences, Isfahan, Iran Telefax: +983136691510 Email: h_tavakoli@med.mui.ac.ir

Received: 28 Jul. 2017

Accepted: 09 Dec. 2017
}

\section{ABSTRACT}

\section{BACKGROUND}

Cholecystitis is a common surgical condition. Recently, several authors have reported that DNA of bile tolerant Helicobacter spp. has been found in the human bile colonizing the biliary tract. The aim of this study was to evaluate the association between the presence of Helicobacter spp. and gallstone cholecystitis.

\section{METHODS}

In this case-control study, gallstones, bile, and gallbladder mucosa were collected from 25 patients without gallstone disease, 24 with acute cholecystitis, and 28 with chronic cholecystitis. The presence of Helicobacter pylori (H. pylori), Helicobacter bilis (H. bilis), Helicobacter hepaticus (H. hepaticus), and Helicobacter pullorum (H. pullorum) were investigated by polymerase chain reaction (PCR) using species-specific primers.

\section{RESULTS}

In this study, 77 subjects with acute and chronic cholecystitis and control groups with a mean age of $46.85 \pm 14.53$ years, including 58 (67.25\%) women and 19 (32.75\%) men were included. DNA of 10 Helicobacter spp. was detected in the bile of the patients with cholecystitis including eight $H$. pylori and two H. bilis. However, we could not detect H. hepaticus and H. pullorum DNA in the samples. Moreover, there was an association between $H$. pylori and acute cholecystitis $(p=0.048)$, which was found to be stronger in 31-40-year-olds group $(p=0.003)$.

\section{CONCLUSION}

We found an association between the presence of H. pylori DNA and acute gallstone cholecystitis. There is not statistically significant correlation between three enterohepatic Helicobacter spp. (H. bilis, H. hepaticus, and H. pullorum) and cholelithiasis. Given the low sample size of the patients, more studies are required to clear the clinical role of Helicobacter spp. in the gallstone disease and cholecystitis.

KEYWORDS:

H. pylori, H. bilis, H. heopaticus, H. pullorum, Gallstone, Cholecystitis

Please cite this paper as:

Fatemi SM, Doosti A, Shokri D, Ghorbani-Dalini S, Molazadeh M, Tavakoli H, Minakari M, Tavakkoli H. Is There a Correlation between Helicobacter Pylori and Enterohepatic Helicobacter Species and Gallstone Cholecystitis? Middle East J Dig Dis 2018;10:24-30. doi: $10.15171 /$ mejdd.2017.86.

\section{INTRODUCTION}

Helicobacter pylori (H. pylori) is a widespread gram-negative bacillus, which colonizes primarily the stomach and can probably cause the most common chronic bacterial infection worldwide. ${ }^{1}$ During the last two decades, research on the Helicobacter genus has focused on $H$. pylori linked to duodenal and gastric 
ulcers $^{1,2}$ gastric adenocarcinoma, ${ }^{3-5}$ and non-Hodgkin's lymphomas of the stomach. ${ }^{67}$

Moreover, detecting H. pylori DNA in cholesterol gallstone may indicative $H$. pylori colonization as a predisposing factor for gallstone formation in gallbladder. ${ }^{8,9}$ Some studies concluded that $H$. pylori infection in the gallbladder not only might lead to cholelithiasis but also was a risk factor for cholecystitis. ${ }^{10-12}$ Contrary to mentioned research, Fallone and colleagues in the first North American investigation address the issue of Helicobacter in bile of the patients who underwent endoscopic retrograde cholangiopancreatography for hepatobiliary conditions. All 122 patients with hepatobiliary disease including 75 patients with gallstone disease had no $\mathrm{He}$ licobacter DNA. ${ }^{13}$ Moreover, two studies in human and animal model suggest that $H$. pylori infection dose not play a significant role in gallstone formation. ${ }^{14-16}$

In addition, some Helicobacter spp. are resistant to bile and recent interest has linked the presence of H. pylori and some of enterohepatic Helicobacter spp. in hepatobiliary diseases in human and animals. ${ }^{17-18}$ Enterohepatic Helicobacter species (EHS) that colonize the hepatobiliary tract of humans include Helicobacter hepaticus (H. hepaticus), Helicobacter bilis ( $H$. bilis), Helicobacter rappini ( $H$. rappini), Helicobacter ganmani (H. ganmani), and Helicobacter pullorum (H. pullorum). Several of these EHS are associated with the pathogenesis of chronic biliary disorders, such as cholecystitis, and cholelithiasis. ${ }^{19-20}$

Therefore, in this study we attempted to determine any potential association between Helicobacter species, particularly H. pylori, H. hepaticus, H. bilis, and H. pullorum and gallstone diseases in Iranian patients.

\section{MATERIALS AND METHODS}

\section{Ethical approval}

The study protocol and informed consent form were reviewed and approved by the Regional Research Ethics Committee of Isfahan University of Medical Sciences. Informed consent was obtained from all patients before their enrollment in the study according to the Helsinki's Declaration.

\section{Sampling}

Collection of samples was performed in Alzahra University Hospital in Isfahan, Iran. Patients were excluded if they were taking antibiotic courses (more than 5 days) within 3 months before sample collection. It is important to mention that all patients in acute and chronic cholecystitis groups had received between one to four doses of antibiotic before cholecystectomy. Serum samples were stored at $-20^{\circ} \mathrm{C}$ until use.

The study population consisted of 77 subjects who were examined prospectively. The subjects were categorized into three groups. The first group consisted of 25 patients without gallstone related biliary disease with the mean age of $46.24 \pm 13.84$ years (range 28-71 years) who underwent endoscopic retrograde cholangiopancreatography (ERCP) as control group, including 6 men and 19 women. The second group consisted of 24 individuals with the mean age of $47.94 \pm 14.73$ years (range 22-76 years) including 7 men and 17 women. These patients underwent laparoscopic cholecystectomy and were diagnosed as having gallstone related acute cholecystitis based on history, physical examination, and sonography, which were confirmed by pathological report. The third group consisted of 28 individuals with the mean age of $45.64 \pm$ 11.33 years (range 22-79 years) including 7 men and 21 women. These individuals underwent laparoscopic cholecystectomy because of gallstone and repeated attacks of biliary colic and were diagnosed as having chronic cholecystitis in the pathological report.

The three groups were comparable in age, sex, and body mass index (BMI) composition. BMI was calculated in the day of surgery and divided into four categories including underweight $(\leq 18.5)$, normal weight (18.5-24.9), overweight (25-29.9), and obese ( $\geq 30$ ).

Serum and bile samples of the control group, as well as serum, gallstones, bile, and gallbladder mucosa samples of the patients with gallstone diseases undergoing laparoscopic cholecystectomy, were collected. To avoid contamination with the gastrointestinal bacterial flora, the bile samples were immediately obtained by direct aspiration from cholecystectomized specimens or by aspiration of bile after the first cannulation of common bile duct in ERCP. Aspirated bile samples and biopsies collected in phosphate buffer saline (PBS) were stored at $-20^{\circ} \mathrm{C}$ until DNA was isolated. For H. pylori culture 0.5 $\mathrm{mL}$ of bile was used. An enzyme-linked immunosorbent assay (ELISA) test was also carried out on serum samples to determine the H. pylori infectious state of all patients. 


\section{Microbiological study}

The bile were separately homogenized in $0.5 \mathrm{~mL}$ of broth in a glass tissue grinder and plated into Petri dishes containing freshly prepared Richard Agar (Merck, Germany) medium, optimized for growth of coccoid form of Helicobacter ${ }^{21}$ The plates were incubated under microaerophilic conditions at $37^{\circ} \mathrm{C}$ for up to 21 days.

\section{DNA extraction}

DNA was extracted from bile, biliary epithelium, and gallstones with a QIAamp DNA Mini kit (QIAGen $\mathrm{GmbH}$, Hilden, Germany) according to the manufacturer's recommendations, with minor modifications. ${ }^{22}$

\section{Preparation of samples}

The bile samples were thawed at room temperature. About $200 \mu \mathrm{L}$ of each bile was diluted with an equal volume of $\mathrm{PBS}$ with $\mathrm{pH}$ adjusted to 7.4-7.6 and washed three times with centrifugation at $18000 \mathrm{~g}$ for $15 \mathrm{~min}$, and the supernatant was discarded in order to remove some of the inhibitors present in bile.

In the case of gallbladder tissue, it was washed with deionized distilled water for removing some of the bile. Then it was washed with PBS similarly for removing some of the inhibitors present in the bile. DNA was extracted from about $50 \mathrm{mg}$ of the homogenized superficial cell layers and mucous of gallbladder tissue.

The supernatant of DNA extract was stored at $-22^{\circ} \mathrm{C}$, ready to be used for polymerase chain reaction (PCR) amplification. Purity was estimated spectrophotometrically at OD260/280. In order to determine the lower limit of detection of the extraction protocol for bile components, bile was spiked with tenfold serial dilutions of live H. pylori cell (ATCC strain 43504) suspension. These samples were processed and DNA extraction was performed in parallel with other samples.

In the case of gallstone, after washing with PBS, each gallstone was cut through the center and the inner matrix was obtained by scraping into a clean culture dish using a sterile blade. DNA was extracted by using a modified method of Swidsinki and colleagues. ${ }^{23}$

\section{Bile inhibitory test}

To test the inhibitory effect of bile components on PCR procedure, we spiked 10 randomly selected nega- tive bile with pure $H$. pylori and prepared a standard suspension of bacteria according to the 0.5 McFarland tube. Tenfold serial dilutions of the $H$. pylori cell suspension were made and the bile samples were spiked with these concentrations. These samples were processed and DNA extraction was performed in parallel with other samples.

\section{Helicobacter species-specific PCR amplification and PCR conditions}

The presence of $H$. pylori in DNA extracted from these samples was determined using Helicobacter hsp60 gene specific primers, ${ }^{24}$ and the presence of $\mathrm{H}$. hepaticus, ${ }^{25} \mathrm{H}$. bilis, ${ }^{26}$ and $H$. pullorum ${ }^{27}$ in the DNA extracted from these samples was determined using species-specific $16 \mathrm{~S}$ rRNA genes by PCR that is described in table 1. PCR amplification was performed in a total volume of $25 \mu \mathrm{L}$ in $0.5 \mathrm{~mL}$ containing $1 \mu \mathrm{g}$ of the extracted DNA sample, $1 \mu \mathrm{M}$ of each of the primers, $2 \mathrm{mM} \mathrm{MgCl} 2,200 \mu \mathrm{M}$ deoxynucleoside triphosphates, $2.5 \mu \mathrm{L}$ of $10 \mathrm{X}$ PCR buffer (10 mM Tris- $\mathrm{HCl}, 1.5 \mathrm{mM} \mathrm{MgCl} 2,50 \mathrm{mM} \mathrm{KCl} \mathrm{[pH}$ 8.3]) and 1 unit of Taq DNA polymerase (Roche applied science, Germany). All oligonucleotide primers were synthesized by CinaGene (CinaGene Co, Tehran, Iran). Amplification was done by using Mastercycler Gradient Thermal Cycler (Eppendorf, Germany). Aliquots of 10 $\mu \mathrm{L}$ of PCR amplified products were separated electrophoretically. For this reason, PCR products were applied to the gel in parallel with DNA ladders (GeneRuler ${ }^{\mathrm{TM}}$ 100 bp Plus DNA Ladder Fermentas, Germany) to determine reaction product sizes. Constant voltages of $80 \mathrm{~V}$ for $30 \mathrm{~min}$ were used for products separation. After electrophoresis, the gel was stained with ethidium bromide and images were obtained by UVIdoc gel documentation systems (UK). The extracted DNA sample was replaced by distilled water as a negative control.

\section{Measurement of $\boldsymbol{H}$. pylori-specific immunoglobulin G}

Presence of $H$. pylori-specific immunoglobulin G was determined quantitatively by ELISAs in the serum samples of the patients using a commercial ELISA kit (Monobind $\AA$, Monobind, Inc., United States). Duplicates of 1:100 diluted serum samples were assayed according to the manufacturer's recommendations. The titer of 20 $\mathrm{NTU} / \mathrm{mL}$ was given as cut-off value as recommended by 
Table 1: Primer sequences and PCR cycling conditions used for Helicobacter spp. identification

\begin{tabular}{|c|c|c|c|c|c|}
\hline Organism & Target & Sequence (5' to $\left.3^{\prime}\right)$ & Cycle & Amplicons (bp) & reference \\
\hline H. hepaticus & 16S rRNA & $\begin{array}{l}\text { F:GCATTTGAAACTGTTACTCTG } \\
\text { R:CTGTTTTCAAGCTCCCC }\end{array}$ & $\begin{array}{c}\left(95^{\circ} \mathrm{C}, 5 \mathrm{~min}\right. \\
94^{\circ} \mathrm{C}, 30 \mathrm{~s} ; \\
59^{\circ} \mathrm{C}, 30 \mathrm{~s} \\
72^{\circ} \mathrm{C}, 30 \mathrm{~s} \\
\left.72^{\circ} \mathrm{C}, 5 \mathrm{~min}\right) \\
\text { (30 cycles) }\end{array}$ & 417 & Fox et al. ${ }^{28}$ \\
\hline H. bilis & 16S rRNA & $\begin{array}{l}\text { F:CAGAACTGCATTTGAAACTAC } \\
\text { R:AAGCTCTGGCAAGCCAGC }\end{array}$ & $\begin{array}{c}\left(95^{\circ} \mathrm{C}, 5 \mathrm{~min}\right. \\
94^{\circ} \mathrm{C}, 30 \mathrm{~s} ; \\
56^{\circ} \mathrm{C}, 30 \mathrm{~s} \\
72^{\circ} \mathrm{C}, 30 \mathrm{~s} \\
\left.72^{\circ} \mathrm{C}, 5 \mathrm{~min}\right) \\
\text { (30 cycles) }\end{array}$ & 405 & Hamada et al. ${ }^{26}$ \\
\hline H. pylori & Hsp60 & $\begin{array}{l}\text { F:AAGGCATGCAATTTGATAGAGGCT } \\
\text { R:CTTTTTTCTCTTTCATTTCCACTT }\end{array}$ & $\begin{array}{c}\left(95^{\circ} \mathrm{C}, 5 \mathrm{~min}\right. \\
94^{\circ} \mathrm{C}, 30 \mathrm{~s} ; \\
56^{\circ} \mathrm{C}, 30 \mathrm{~s} \\
72^{\circ} \mathrm{C}, 30 \mathrm{~s} \\
\left.72^{\circ} \mathrm{C}, 5 \mathrm{~min}\right) \\
\text { (30 cycles) }\end{array}$ & 501 & Singh et al..$^{24}$ \\
\hline H. pullorum & 16S rRNA & $\begin{array}{l}\text { F:ATGAATGCTAGTTGTTGTGAG } \\
\text { R:GATTGGCTCCACTTCACA }\end{array}$ & $\begin{array}{c}\left(95^{\circ} \mathrm{C}, 5 \mathrm{~min}\right. \\
94^{\circ} \mathrm{C}, 30 \mathrm{~s} ; \\
60^{\circ} \mathrm{C}, 60 \mathrm{~s} \\
72^{\circ} \mathrm{C}, 80 \mathrm{~s} \\
\left.72^{\circ} \mathrm{C}, 5 \mathrm{~min}\right) \\
(40 \text { cycles })\end{array}$ & 467 & Stanley et al. ${ }^{27}$ \\
\hline
\end{tabular}

Table 2: Relation between age of the patients, cholecystitis, and number of samples positive for $\boldsymbol{H}$. pylori and $\boldsymbol{H}$. bilis in PCR assays

\begin{tabular}{lcccccc}
\hline & \multicolumn{2}{c}{$\begin{array}{c}\text { Chronic cholecystitis } \\
\mathbf{n ~ ( \% )}\end{array}$} & $\begin{array}{c}\text { Acute cholecystitis } \\
\mathbf{n}(\mathbf{\%})\end{array}$ & \multicolumn{2}{c}{$\begin{array}{c}\text { Control group } \\
\text { n (\%) }\end{array}$} \\
\hline Patients age & H. pylori & H. bilis & H. pylori & H. bilis & H. pylori & H. bilis \\
\hline$<20$ & $0(0)$ & $0(0)$ & $0(0)$ & $0(0)$ & $0(0)$ & $0(0)$ \\
\hline $21-30$ & $1(3.58)$ & $0(0)$ & $0(0)$ & $0(0)$ & $0(0)$ & $0(0)$ \\
\hline $31-40$ & $0(0)$ & $1(3.58)$ & $3(12.5)$ & $1(4.16)$ & $1(4)$ & $0(0)$ \\
\hline $41-50$ & $0(0)$ & $0(0)$ & $1(4.16)$ & $0(0)$ & $0(0)$ & $0(0)$ \\
\hline $51-60$ & $1(3.58)$ & $0(0)$ & $1(4.16)$ & $0(0)$ & $0(0)$ & $0(0)$ \\
\hline $61-70$ & $0(0)$ & $0(0)$ & $1(4.16)$ & $0(0)$ & $1(4)$ & $0(0)$ \\
\hline$>70$ & $0(0)$ & $0(0)$ & $0(0)$ & $0(0)$ & $0(0)$ & $0(0)$ \\
\hline Total & $2(7.14)$ & $1(3.58)$ & $6(25)$ & $1(4.16)$ & $2(8)$ & $0(0)$ \\
\hline
\end{tabular}

the manufacturer for serum samples. Thus any titer $>20$ was considered positive.

\section{RESULTS}

In this study, 77 patients with acute and chronic cholecystitis and subjects of control groups with a mean age of $46.85 \pm 14.53$ consisting of $58(67.25 \%)$ women and 19 (32.75\%) men were included. They were divided into 6 age groups for statistical analysis. There was no significant difference in age, sex, and BMI $(p>0.05)$ between the case and control groups. In cholecystitis groups, 39 (75\%) patients were overweight and $7(13.5 \%)$ were obese. No Helicobacter species were detected in gallstone by PCR, and culture samples were all negative for Helicobacter species.

Evaluation of the bile samples for Helicobacter species among all groups (table 2) showed two (7.14\%) H. pylori and one (3.57\%) H. bilis among chronic cholecystitis group and six $(25 \%) H$. pylori and one $(4.16 \%) H$. bilis among acute cholecystitis group. Also, 
Table 3: The prevalence of $\boldsymbol{H}$. pylori immunoglobulin $\mathbf{G}$ positivity among the patients of the three groups

H. pylori-specific immunoglobulin G quantitative ELISAs

Positive* (\%)

\begin{tabular}{lc}
\hline Acute cholecystitis $(\mathrm{n}=24)$ & $21(87.5 \%)$ \\
\hline Chronic cholecystitis $(\mathrm{n}=28)$ & $25(89.2 \%)$ \\
\hline Control $(\mathrm{n}=25)$ & $20(80 \%)$ \\
\hline *Border line values are included. &
\end{tabular}

two $(8 \%) H$. pylori was detected in the control group. Although statistical analysis revealed an association between $H$. pylori and acute cholecystitis $(p=0.048)$, the strong association was found in 31-40 year-olds group ( $p=0.003)$. Laboratory examination for H. pylori IgG revealed no statistically significant differences among all groups $(p>0.05$, table 3$)$.

\section{DISCUSSION}

Pathways of $H$. pylori penetration into the bile have not been completely understood but there are possible routs of $H$. pylori migration and colonization in the biliary tract such as $H$. pylori translocation from the duodenum via sphincter of Oddi and/or its hematogenous spread to the liver and then excretion into the bile..$^{29,30}$

Moreover, HP infection affects the pathophysiology of gallbladder stone formation and its complications, including cholecystitis, cholangitis, pancreatitis, and biliary cancer. One mechanism is releasing large amounts of proinflammatory and vasoactive substances, such as interleukins (IL)-1, IL-6, and tumor necrosis factor (TNF) $-\alpha$ involved in gallbladder inflammatory disorders and pathogenesis of cholelithiasis. ${ }^{31,32}$ In addition, producing oxidative stress and free radical reactions in the gallbladder wall and bile can induce gallstone formation. ${ }^{33}$ Finally, HP infection affecting the apoptotic process, is also involved in chronic cholecystitis. ${ }^{34}$

A study from Greece indicates positive HP serology in $51.3 \%$ of patients with calcular biliary and pancreatic disease versus $19.3 \%$ in histology of gallbladder tissue, which is the gold standard for diagnosis of HP infection. ${ }^{35}$ Another investigation in Germany showed that patients with gallstones were 3.5 times more likely to have $H$. $p y$ lori in the bile compared with patients in a control group. ${ }^{30}$

The H. pylori infection rate is very high in Iran. The overall reported infection rate is about $60-80 \%$ in various parts of Iran and is correlated with age. ${ }^{36}$ It is compatible with high frequency of positive $H$. pylori antibody in case and control groups without significant difference.

$H$. pylori is very difficult to grow on culture media because of the microaerophilic characteristics of this organism as it dies if it has any contact with air. ${ }^{37}$ Also, H. pylori exists predominantly in a non-culturable coccoid form outside the stomach. This is because bile has a chemorepellent effect on $H$. pylori as well as an oxygen concentration under the optimum value $(<7 \%) .{ }^{38}$ This may explain why we could not detect $H$. pylori among the studied cases using culture methods. This finding is compatible with previous studies.

Using sequencing of PCR-amplified 16S rRNA gene fragments, DNA from $H$. bilis was also detected in the gallbladders of five out of eight Chileans with chronic cholecystitis. $^{39}$ In our study, 10 (19.2\%) Helicobacter spp. DNA were detected in the bile of the patient with cholecystitis, of them eight $(15.3 \%)$ were $H$. pylori and two $(3.9 \%)$ were $H$. bilis.

Despite detecting $H$. pullorum by PCR from the bile of the patients with chronic cholecystitis, ${ }^{20}$ no $H$. pullorum was detected in the bile samples of the patients with cholecystitis in our study.

One study from Nepal showed that there was a common association (76.66\%) between H. hepaticus and cholelithiasis ${ }^{40}$ but in our study, $H$. hepaticus was not detected in the bile samples of the patients with cholecystitis.

These discrepancies between the results of investigations about the association of gallstone cholecystitis and Helicobacter species in different countries or areas may be due to differences in the epidemiology of Helicobacter, used PCR methods, and inappropriate control groups.

There are limitations to our study. All the patients in acute and chronic cholecystitis groups should have received antibiotic, in the first group as standard of care and in the second group, a single dose of antibiotic as prophylaxis before surgery. All patients who had received antibiotic courses (more than 5 days) were excluded from the study. Despite this limitation, it seems that antibiotic use has not influenced the results, because we found more $H$. pylori infection in acute cholecystitis group despite more doses of antibiotic prescribed before surgery.

Although, there are multiple studies about Helicobacter and gall stone disease, there is limited data about 
relation between $H$. pylori and several enterohepatic Helicobacter species with calculus cholecystitis especially in Iran. Due to diversity and epidemiological differences of Helicobacter species based on geographic areas, this research may be considered important from epidemiological and pathophysiological points of view.

\section{CONCLUSION}

In summary, we found an association between the presence of $H$. pylori DNA and acute cholecystitis with gallstone, especially in 31-40-year-olds group. Moreover, there is not statistically significant correlation between the three enterohepatic Helicobacter species (H. bilis, H. hepaticus, and H. pullorum) and cholelithiasis. Given the low sample size of the patients, more studies are required to clear the clinical role of Helicobacter spp. in the gallstone disease and cholecystitis.

\section{CONFLICT OF INTEREST}

The authors declare no conflict of interest related to this work.

\section{REFERENCES}

1. Blaser MJ, Chyou PH, Nomura A. Age at establishment of Helicobacter pylori infection and gastric carcinoma, gastric ulcer, and duodenal ulcer risk. Cancer Res 1995;55:562-5.

2. Peterson WL. Helicobacter pylori and peptic ulcer disease. $N$ Engl J Med 1991;324:1043-8. doi: 10.1056/ NEJM199104113241507.

3. Parsonnet J. Helicobacter pylori and gastric cancer. Gastroenterol Clin North Am 1993;22:89-104.

4. Suzuki H, Iwasaki E, Hibi T. Helicobacter pylori and gastric cancer. Gastric Cancer 2009;12:79-87. doi: 10.1007/ s10120-009-0507-x.

5. Forman D. Helicobacter pylori and gastric cancer. Scand J Gastroenterol Suppl 1996;31:23-6. doi: $10.3109 / 00365529609094746$

6. Parsonnet J, Hansen S, Rodriguez L, Gelb AB, Warnke RA, Jellum E, et al. Helicobacter pylori infection and gastric lymphoma. $N$ Engl J Med 1994;330:1267-71. doi: 10.1056/NEJM199405053301803.

7. Eidt S, Stolte M, Fischer R. Helicobacter pylori gastritis and primary gastric non-Hodgkin's lymphomas. J Clin Pathol 1994;47:436-9. doi: 10.1136/jcp.47.5.436.

8. Monstein HJ, Jonsson Y, Zdolsek J, Svanvik J. Identification of Helicobacter pylori DNA in human cholesterol gallstones. Scand J Gastroenterol 2002;37:112-9. doi: $10.1080 / 003655202753387455$.
9. Farshad S, Alborzi A, Malek Hosseini SA, Oboodi B, Rasouli M, Japoni A, et al. Identification of Helicobacter pylori DNA in Iranian patients with gallstones. Epidemiol Infect 2004;132:1185-9. doi: 10.1017/S0950268804002985.

10. Abro AH, Haider IZ, Ahmad S. Helicobacter pylori infection in patients with calcular cholecystitis: a hospital based study. J Ayub Med Coll Abbottabad 2011;23:30-3.

11. Guraya SY, Ahmad AA, El-Ageery SM, Hemeg HA, Ozbak HA, Yousef K, et al. The correlation of Helicobacter Pylori with the development of cholelithiasis and cholecystitis: the results of a prospective clinical study in Saudi Arabia. Eur Rev Med Pharmacol Sci 2015;19:3873-80.

12. Javaherzadeh M SA, Sabet B, Mousavi-Almaleki SA MA. Simultaneous Helicobacter Pylori Infection in Gastric Mucosa and Gallbladder; Is There Any Relationship? Acada J Surg 2016;3:12-14.

13. Fallone CA, Tran S, Semret M, Discepola F, Behr M, Barkun AN. Helicobacter DNA in bile: correlation with hepato-biliary diseases. Aliment Pharmacol Ther 2003;17:453-8. doi: 10.1046/j.1365-2036.2003.01424.x.

14. Maurer KJ, Rogers AB, Ge Z, Wiese AJ, Carey MC, Fox JG. Helicobacter pylori and cholesterol gallstone formation in $\mathrm{C} 57 \mathrm{~L} / \mathrm{J}$ mice: a prospective study. Am J Physiol Gastrointest Liver Physiol 2005;290:G175-82. doi: 10.1152/ajpgi.00272.2005.

15. Chen W, Li D, Cannan RJ, Stubbs RS. Common presence of Helicobacter DNA in the gallbladder of patients with gallstone diseases and controls. Dig Liver Dis 2003;35:237-43. doi: 10.1016/S1590-8658(03)00060-4.

16. Griniatsos J, Sougioultzis S, Giaslakiotis K, Gazouli M, Prassas E, Felekouras E, et al. Does Helicobacter pylori identification in the mucosa of the gallbladder correlate with cholesterol gallstone formation? West Indian Med J 2009;58:428-32.

17. Avenaud P, Marais A, Monteiro L, Le Bail B, Bioulac Sage P, Balabaud C, et al. Detection of Helicobacter species in the liver of patients with and without primary liver carcinoma. Cancer 2000;89:1431-9. doi: 10.1002/1097-0142(20001001)89:7<1431::AIDCNCR4 $>3.0 . \mathrm{CO} ; 2-5$

18. Apostolov E, Al-Soud WA, Nilsson I, Kornilovska I, Usenko V, Lyzogubov V, et al. Helicobacter pylori and other Helicobacter species in gallbladder and liver of patients with chronic cholecystitis detected by immunological and molecular methods. Scand J Gastroenterol 2005;40:96-102. doi: 10.1080/00365520410009546.

19. Maurer KJ, Ihrig MM, Rogers AB, Ng V, Bouchard G, Leonard MR, et al. Identification of cholelithogenic enterohepatic helicobacter species and their role in murine cholesterol gallstone formation. Gastroenterology 2005;128:1023-33.

20. Karagin PH, Stenram U, Wadstrom T, Ljungh A. Helicobacter species and common gut bacterial DNA in gallbladder with cholecystitis. World J Gastroenterol 2010;16:4817-22. doi: 10.3748/wjg.v16.i38.4817. 
21. Richards CL, Buchholz BJ, Ford TE, Broadaway SC, Pyle BH, Camper AK. Optimizing the growth of stressed Helicobacter pylori. Journal of Microbiological Methods 2011;84:174-82. doi: 10.1016/j.mimet.2010.11.015.

22. Monteiro L, Gras N, Vidal R, Cabrita J, Mégraud F. Detection of Helicobacter pylori DNA in human feces by PCR: DNA stability and removal of inhibitors. $J \mathrm{Mi}-$ crobiol Methods 2001;45:89-94. doi: 10.1016/S01677012(01)00225-1.

23. Swidsinski A, Ludwig W, Pahlig H, Priem F. Molecular genetic evidence of bacterial colonization of cholesterol gallstones. Gastroenterology 1995;108:860-4.

24. Singh V, Mishra S, Rao G, Jain AK, Dixit V, Gulati $\mathrm{AK}$, et al. Evaluation of nested PCR in detection of Helicobacter pylori targeting a highly conserved gene: HSP60. Helicobacter 2008;13:30-4. doi: 10.1111/j.15235378.2008.00573.x.

25. Fox J, Yan L, Dewhirst F, Paster B, Shames B, Murphy $\mathrm{J}$, et al. Helicobacter bilis sp. nov., a novel Helicobacter species isolated from bile, livers, and intestines of aged, inbred mice. J Clin Microbiol 1995;33:445-54.

26. Hamada T, Yokota K, Ayada K, Hirai K, Kamada T, Haruma K, et al. Detection of Helicobacter hepaticus in human bile samples of patients with biliary disease. Helicobacter 2009;14:545-51. doi: 10.1111/j.1523-5378.2009.00729.x.

27. Stanley J, Linton D, Burnens AP, Dewhirst FE, On SLW, Porter A, et al. Helicobacter pullorum sp. nov.-genotype and phenotype of a new species isolated from poultry and from human patients with gastroenteritis. Microbiology 1994;140:3441-9. doi: 10.1099/13500872-140-12-3441.

28. Fox JG, MacGregor JA, Shen Z, Li X, Lewis R, Dangler CA. Comparison of methods of identifying Helicobacter hepaticus in $\mathrm{B} 6 \mathrm{C} 3 \mathrm{~F} 1$ mice used in a carcinogenesis bioassay. J Clin Microbiol 1998;36:1382-7.

29. Helaly GF, El-Ghazzawi EF, Kazem AH, Dowidar NL, Anwar MM, Attia NM. Detection of Helicobacter pylori infection in Egyptian patients with chronic calcular cholecystitis. Br J Biomed Sci 2014;71:13-8. doi: 10.1080/09674845.2014.11669957.

30. Bulajic M, Maisonneuve P, Schneider-Brachert W, Muller P, Reischl U, Stimec B, et al. Helicobacter pylori and the risk of benign and malignant biliary tract disease. Cancer 2002;95:1946-53. doi: 10.1002/cncr.10893.

31. Shengelia M, Intskirveli N, Gogebashvili N. Inflammatory markers of gallstones disease in menopausal women. Georgian Med News 2012;208-209:52-5.

32. Kasprzak A, Szmyt M, Malkowski W, Przybyszewska W, Helak-Lapaj C, Seraszek-Jaros A, et al. Analysis of immunohistochemical expression of proinflammatory cytokines (IL-1alpha, IL-6, and TNF-alpha) in gallbladder mucosa: comparative study in acute and chronic calculous cholecystitis. Folia Morphol 2015;74:65-72. doi: 10.5603/FM.2015.0011.

33. Sipos P, Gamal EM, Blazovics A, Metzger P, Miko I, Furka I. Free radical reactions in the gallbladder. Acta Chir
Hung 1997;36:329-30.

34. Hundal R, Shaffer EA. Gallbladder cancer: epidemiology and outcome. Clin Epidemiol 2014;6:99-109. doi: 10.2147/CLEP.S37357.

35. Kountouras J, Tsiaousi E, Trigonis S, Zavos C, Kouklakis G. Helicobacter pylori infection in a Greek cohort with biliary disease. Br J Biomed Sci 2014;71:178-9. doi: 10.1080/09674845.2014.11669984.

36. Khedmat H, Karbasi-Afshar R, Agah S, Taheri S. Helicobacter pylori Infection in the general population: A Middle Eastern perspective. Caspian J Intern Med 2013;4:745-53.

37. Abrams DN, Koslowsky I, Matte G. Pharmaceutical interference with the [14C] carbon urea breath test for the detection of Helicobacter pylori infection. J Pharm Pharm Sci 2000;3:228-33.

38. Neri V, Margiotta M, de Francesco V, Ambrosi A, Valle $\mathrm{ND}$, Fersini A, et al. DNA sequences and proteic antigens of $H$. pylori in cholecystic bile and tissue of patients with gallstones. Aliment Pharmacol Ther 2005;22:715-20. doi: 10.1111/j.1365-2036.2005.02644.x.

39. Fox JG, Dewhirst FE, Shen Z, Feng Y, Taylor NS, Paster BJ, et al. Hepatic Helicobacter species identified in bile and gallbladder tissue from Chileans with chronic cholecystitis. Gastroenterology 1998;114:755-63. doi: 10.1016/S0016-5085(98)70589-X.

40. Pradhan SB. Study of Helicobacter hepaticus in gallbladders with cholelithiasis and its sensitivity pattern. Kathmandu Univ Med J (KUMJ) 2009;7:125-8. doi: 10.3126/ kumj.v7i2.2704. 